\title{
From Orientalsim to Postcoloniality
}

Orientalsim and postcoloniality are synonymous with contemporary culture and literature. As much as the younger generations of formally colonized nations and communities would like to argue, the truth of the matter is that 
on some level, their colonial times have made an everlasting impression on their own identity and culture. This was one of the many themes that the conference, held at the Södertörns Högskola University College in Stockholm, Sweden, focused on during its congested four-day program.

This was one of the largest gatherings to deal with issues of ethnic identity and diversity, as well as the non-proverbial influences of colonialism in the reshaping of new communities and their modernized cultures. Papers presented ranged from diversity and nationalism in the postcolonial context, postcolonialsim and religious studies, African-American writing and social activism, colonial romanticism and white supremacy, and postcolonial literature and film in English, among other topics.

This may have been the first postcolonial conference of this size and scope in Sweden. In her welcome speech, conference organizer Kerstin Shands (professor, Department of English) mentioned that participants had come from Saudi Arabia, Bahrain, Malawi, Malaysia, Sri Lanka, India, Taiwan, Hong Kong, the United States, Japan, Croatia, Northern Ireland, South Africa, and Britain, and that the organizers had been surprised by the amount of interest elicited. Clearly, this interest testifies to the topic's importance.

Postcolonial critics need to deal with occidentalist or anti-western perspectives, along with a renewed attention to the "otherness" of the "other." Also on the agenda were concerns about religion and the sacred, as well as the natural environment. Postcolonialism may finally be in the process of desecularizing itself. The papers presented were thought-provoking, to say the least.

In the first "Black American Writing and Social Activism" workshop, Fredrik Sunnermark (senior lecturer, Cultural Studies, University West, Trollhättan, Sweden) presented "Sameness and Difference: The Paradoxical Meaning of the 'Negro' in the Rhetoric of Martin Luther King, Jr." Mariangela Palladion (Ph.D. candidate, University of Stratchclyde, Glasgow, UK) spoke on "History, Postcolonialism, and Postmodernism in Toni Morrison's Beloved," which The New York Times recently named the best work of American fiction in the last 25 years. She provided an analytical look into this book by drawing religious allegories from within the context of the characters and their stories. At the end of the workshop, author, poet, artist, and lecturer Shay Youngblood (Jamaica Plain, MA) tackled the topic of "Transforming the Personal into the Proverbial: Subversive Fictions in Print and on Canvas." $\mathrm{He}$ focused on the significance of art and literature (and combining them into one art form), maintaining that they can be applied in such a way as to address issues that reflect a postcolonial world. 
On the second day, I attended the workshop "Windows of Change: Decolonisation or Re-colonisation?" chaired by Donald Christian (instructor, Södertörn University College) and John Forward (instructor, Department of English, Södertörn University College). This session featured an intriguing look back into the history and process of de-colonization in the Middle and Far East by Major Simon Williams (retired, Sweden), who had served as a British army officer in the Persian Gulf and focused on the significance and impact of this process on the local communities. John Forward's paper on "Harold McMillan: A Metaphor?" delved into the characterizations and principals of the man, as well as his accomplishments, and touched upon his relationship with assassinated American president John F. Kennedy. This topic was also addressed by Ian Bald (American Embassy, Sweden) in his "The Life and Times of John F. Kennedy." The discussions veered into the imperialistic domination of powerful states throughout history and compared the British Empire and its colonization policy with today's empire, the United States, and its international policy.

In the first session of the "Postcolonial Literature and Film in English" workshop, Amit Ray (lecturer, Department of Language and Literature, Rochester Institute of Technology, USA) presented "Of Booker and Spice and Everything Nice: Indian-ness Literary Prizes and Cosmopolitan Culture." His absorbing analysis questioned the reasons behind the dominance of postcolonial literature on the literary prize scene, highlighting in particular the various winning titles of the Man Booker Prize coming out of India. Rose Bloem (Skovde University, Sweden) addressed "The Spectre of the 'Other,"' giving examples in Charlotte Brontë's Jane Eyre, Jean Rhys' Wide Sargasso Sea, and Nadine Gordimer's A Sport of Nature. The session ended with an animated presentation by Osita Ezeliora (instructor, School of Literature and Language Studies, University of the Witwatersrand, Johannesburg, South Africa) on the "Subject of the Other: Location of the Self in Zoë Wicomb's Post-Apartheid Post-colony." She argued that Wicomb's literature is a raw and accurate account of life in postcolonial Africa and dismissed the myths and tainted images produced by other literatures.

The conference also featured a short documentary film, "Models of Success," which featured a group of Arab Muslim women from the Persian Gulf region and highlighted their role in supporting and developing their communities through their active involvement in various training and education programs for youths. The women featured all come from humble backgrounds and have broken new ground by achieving remarkable feats in otherwise male-dominant Arab societies. The film, in English, was written, 
directed, and produced by Art L. Jones (English instructor, University of Bahrain) and coproduced by Ali Al Saeed (writer/author, Baharin), who attended the conference.

Among the various keynote lectures was one on "Said and the Critics: The Historical and Orientalist Response," presented by Nigel Wood (professor, Department of English, University of Loughborough, UK), who shed light on Edward Said's relationship with literary and social criticism and his critique of it from both a historical and an orientalist perspective, and the impact that such views have had on modern thinking.

The first day featured three keynote lectures: Anthony Grooms (writer and professor of creative writing, Kennesaw State University, Georgia, USA) on "Civil Rights Movement Narrative and the American Civic Place," Inga Brandell (associate professor, Department of Political Science, Södertörn University) on "Revisiting Ibn Khaldun: Contemporary Use and Misuse of Classical Arab Science," and Irina Sandomirskaja (professor of culture studies, The Baltic and East European Graduate School, Södertörn University) on "One-sixth of the World: Avantgrade Film, Revolutionary Language and the Colonization of the Periphery in the USSR during the 1920s."

The Literary Salon, convened on the conference's final day, featured readings and recitals by writers and authors Shay Youngblood (Big Mamma Stories, Soul Kiss, and Black Girl in Paris), Anthony Grooms (Bombingham), Dilruba Ara (A List of Offences), and Marisa Villagra. 